\title{
Primary oat cell carcinoma of the trachea
}

\author{
AJAIB S SOORAE AND JOHN R P GIBBONS \\ From the Thoracic Surgical Unit, Royal Victoria Hospital, Grosvenor Road, Belfast BT12 6BA, \\ Northern Ireland
}

Primary malignant tumours of the trachea are so uncommon that they are not even mentioned in many textbooks or are referred to only briefly. Oat cell carcinoma of the trachea is so rare that only five detailed case reports have been published (see table).

\section{Case report}

A 47-year-old man complained of cough and intermittent haemoptysis for three months. The haemoptysis varied from streaking of the sputum to frank blood. He had lost about $3 \mathrm{~kg}$ over one month. He gave no history of wheeze, shortness of breath, or chest pain but stated that he smoked about 15 cigarettes a day.

He looked well, was not anaemic, and had no respiratory distress or stridor. He had good air entry over both lungs and no added sounds. The liver was not palpable.

A full blood count, liver function tests, and routine blood electrolytes gave normal results. A ${ }^{\omega}$ chest radiograph showed no lesion in the lungs and 을 a normal cardiac outline. On bronchoscopy $\mathrm{a}-$ fleshy tumour, which bled easily, was seen about Tr $2 \mathrm{~cm}$ below the vocal cords, arising from the posterior wall of the trachea. The rest of the bronchial tree was normal. A biopsy of the tumour 2 showed an oat cell carcinoma (fig 1). In order to $\overrightarrow{0}$ assess the local extent of the tumour, com- 0 puterised axial tomography (CAT scan) was carried out. This showed considerable distortion of the trachea and thickening of the mediastinum posteriorly and to the left, suggestive of extensive bilateral upper mediastinal lymph node involve- $\frac{\mathrm{Q}}{\mathrm{D}}$ ment (fig 2). A liver scan showed no evidence of 2

Analysis of cases of oat cell carcinoma of the trachea

\begin{tabular}{|c|c|c|c|c|c|c|c|}
\hline Author & $\begin{array}{l}\text { Age and } \\
\text { sex of } \\
\text { patient }\end{array}$ & Symptoms & $\begin{array}{l}\text { Location } \\
\text { of tumour }\end{array}$ & Treatment & Metastasis & Survival & Comment \\
\hline $\begin{array}{l}\text { Pantridge } \\
\text { (1949) }\end{array}$ & $\begin{array}{l}52 \\
\mathbf{M}\end{array}$ & $\begin{array}{l}\text { Haemoptysis, } \\
\text { cough, } \\
\text { dyspnoea, } \\
\text { dysphagia, and } \\
\text { pain in neck }\end{array}$ & Upper third & Tracheostomy & $\begin{array}{l}\text { Liver, } \\
\text { paratracheal } \\
\text { glands, thyroid, } \\
\text { sternoclavicular } \\
\text { joint }\end{array}$ & $\begin{array}{l}\text { Died- } \\
2 \text { months }\end{array}$ & $\begin{array}{l}\text { Exposure to "gas" in } \\
\text { first world war. } \\
\text { Diagnosis at } \\
\text { necropsy }\end{array}$ \\
\hline $\begin{array}{l}\text { Zarowitz and } \\
\text { Hoffman } \\
\text { (1952) }\end{array}$ & $\begin{array}{l}66 \\
\mathbf{M}\end{array}$ & $\begin{array}{l}\text { Haemoptysis, } \\
\text { cough, } \\
\text { dyspnoea, } \\
\text { anorexia, and } \\
\text { weight loss }\end{array}$ & $\begin{array}{l}\text { Upper third } \\
\text { (posterior } \\
\text { wall) }\end{array}$ & $\begin{array}{l}\text { High carbohydrate, } \\
\text { high protein, and } \\
\text { high vitamin diet }\end{array}$ & $\begin{array}{l}\text { Liver, } \\
\text { periportal lymph } \\
\text { nodes }\end{array}$ & $\begin{array}{l}\text { Died- }- \\
1 \text { month }\end{array}$ & $\begin{array}{l}\text { Treated as asthma and } \\
\text { homologous serum } \\
\text { hepatitis. Smoked } 30 \\
\text { cigarettes a day. } \\
\text { Diagnosis at } \\
\text { necropsy }\end{array}$ \\
\hline $\begin{array}{l}\text { Darch } \\
\text { (1962) }\end{array}$ & $\begin{array}{l}42 \\
F\end{array}$ & $\begin{array}{l}\text { Haemoptysis, } \\
\text { cough, } \\
\text { wheeze, and } \\
\text { dyspnoea }\end{array}$ & Lower third & $\begin{array}{l}\text { Radiotherapy, } \\
\text { chemotherapy }\end{array}$ & $\begin{array}{l}\text { Liver, brain, } \\
\text { adrenals, } \\
\text { ovaries }\end{array}$ & $\begin{array}{l}\text { Died- } \\
3 \text { months }\end{array}$ & $\begin{array}{l}\text { Presented with } \\
\text { surgical emphysema } \\
\text { of face, neck, upper } \\
\text { thorax, and } \\
\text { mediastinum }\end{array}$ \\
\hline $\begin{array}{l}\text { Wengraf } \\
(1970)\end{array}$ & $\begin{array}{l}69 \\
F\end{array}$ & $\begin{array}{l}\text { Wheeze and } \\
\text { dyspnoea }\end{array}$ & $\begin{array}{l}\text { Upper third } \\
\text { (posterior } \\
\text { wall) }\end{array}$ & $\begin{array}{l}\text { Radiotherapy, } \\
\text { tracheostomy }\end{array}$ & $\begin{array}{l}\text { Liver, } \\
\text { paratracheal } \\
\text { gland }\end{array}$ & $\begin{array}{l}\text { Died- } \\
4 \& \text { months }\end{array}$ & $\begin{array}{l}\text { Smoked } 30 \\
\text { cigarettes a day. } \\
\text { "Asthma" for } 6 \\
\text { months before } \\
\text { diagnosis }\end{array}$ \\
\hline Jash (1973) & $\begin{array}{l}63 \\
F\end{array}$ & Dyspnoea & Upper third & Radiotherapy & & $\begin{array}{l}\text { Alive at } \\
5 \text { months }\end{array}$ & $\begin{array}{l}\text { Smoked 5-6 } \\
\text { cigarettes a day. }\end{array}$ \\
\hline This study & $\begin{array}{l}47 \\
\mathbf{M}\end{array}$ & $\begin{array}{l}\text { Haemoptysis, } \\
\text { cough, and } \\
\text { weight loss }\end{array}$ & $\begin{array}{l}\text { Upper third } \\
\text { (posterior } \\
\text { wall) }\end{array}$ & $\begin{array}{l}\text { Radiotherapy } \\
\text { chemotherapy }\end{array}$ & & $\begin{array}{l}\text { Alive at } \\
7 \frac{1}{2} \text { months }\end{array}$ & $\begin{array}{l}\text { Smoked } 15 \\
\text { cigarettes a day. } \\
\text { Liver scan showed no } \\
\text { metastasis }\end{array}$ \\
\hline
\end{tabular}




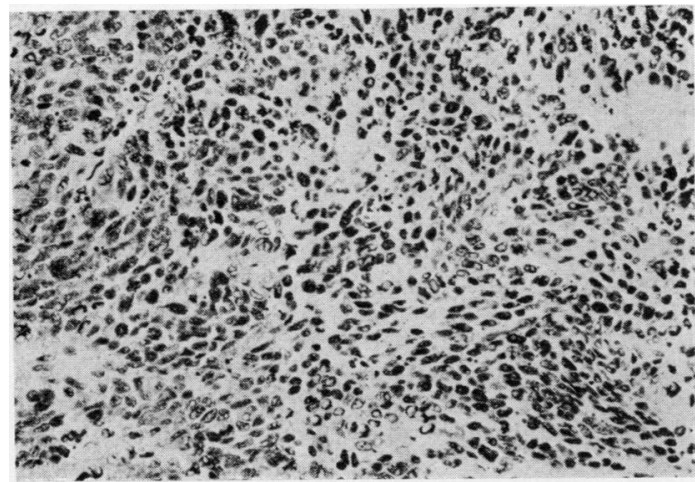

Fig 1 Photomicrograph showing oat cell carcinoma (Haematoxylin and eosin $\times 400$ ).

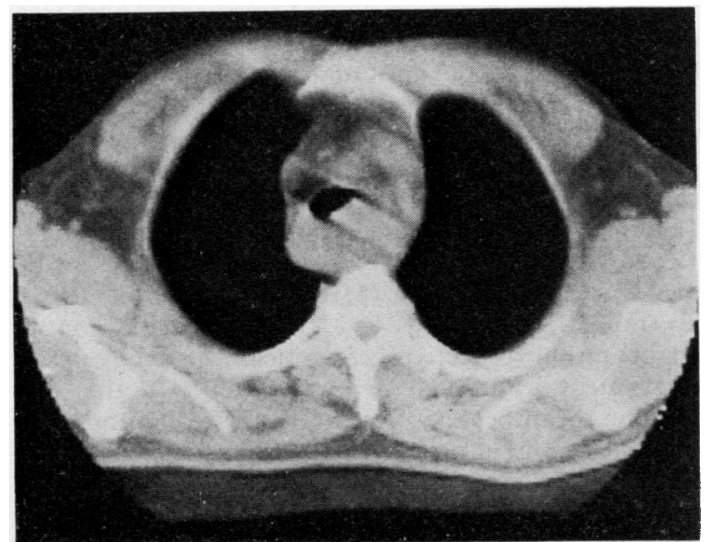

Fig 2 CAT scan showing distortion of trachea and thickening of upper mediastinum.

hepatic metastasis.

The tumour was irradiated with a dose of 4000 rads over a period of three weeks. Bronchoscopy three months later showed the tumour to have completely disappeared. The original tumour site was marked by a whitish plaque surrounded by a zone of erythema. The patient has since been treated with cyclophosphamide. $\mathrm{He}$ is well and asymptomatic seven and a half months later.

\section{Discussion}

Primary oat cell carcinoma of the trachea, which was first reported from Belfast by Pantridge (1949), is the rarest of all tracheal cancers. It is surprising that such a common bronchial tumour should be found so infrequently in the trachea.

Half of tracheal tumours are found in the lower third of the trachea, $33 \%$ in the upper third, and $17 \%$ in the middle third. Five out of the six cases of oat cell carcinoma under review occurred in the upper third (see table). There were three men and three women and the average age was 56.5 years. Four out of the six cases gave a history of cigarette smoking.

Tracheal tumours generally remain asymptomatic for a long time and hence are diagnosed late. Cough, haemoptysis, and dyspnoea were the main presenting symptoms in most patients with oat cell carcinoma. Other less frequent symptoms were wheeze, weight loss, anorexia, dysphagia, and pain. There may be a history of unsuccessful treatment for "adult-onset asthma" (Zarowitz and Hoffman, 1952; Wengraf, 1970). The patient of Darch (1962) presented with surgical emphysema of the face, neck, upper thorax, and mediastinum in addition to the other main symptoms.

Bronchoscopy and biopsy are essential to establish the diagnosis and to assess the local extent of the tumour. Chest radiography is not of great value in tumour detection and was found to be normal in our case. A CAT scan is not only useful for determining extension of the tumour in the mediastinum, but also for detecting any distant metastasis. Tracheal tomography and mediastinoscopy may also help in determining the extent and local spread of the tumour.

Oat cell carcinoma of the trachea has a sinister prognosis because it metastasises early, especially to the liver (see table). Radical surgery is unlikely to alter the natural history of the disease. The tumour is radiosensitive and shortterm palliation was obtained in all four cases in whom a histological diagnosis was made in life. Cytotoxic chemotherapy may further improve the duration and the quality of survival.

\section{References}

Darch, G H (1962). Tracheal neoplasms presenting with mediastinal emphysema. British Journal of Diseases of the Chest, 56, 212-213.

Jash, D K (1973). Oat cell carcinoma of the trachea. Journal of Laryngology and Otology, 87, 681-684.

Pantridge, J F (1949). Primary carcinoma of the trachea. British Journal of Surgery, 37, 48-49.

Wengraf, C (1970). Oat cell carcinoma of the trachea. Journal of Laryngology and Otology, 84, 267-274.

Zarowitz, H, and Hoffman, J B (1952). Primary carcinoma of the trachea. Archives of Internal Medicine, 89, 454-462.

Requests for reprints to: A S Soorae, FRCS, Thoracic Surgical Unit, Royal Victoria Hospital, Grosvenor Road, Belfast BT12 6BA, Northern Ireland. 